\title{
Improved Oxygenation by Steroid Pulse Therapy in Early-Phase Acute Respiratory Distress Syndrome
}

\author{
Yuka Sumi $^{1}$, Hiroshi Ogura ${ }^{1}$, Kouji Akashi², Yoshiki Tohma ${ }^{3}$, Hisayuki Tabuse ${ }^{3}$ \\ Yasuaki Mizushima ${ }^{4}$, Junichirou Yokota ${ }^{5}$, Hisashi Sugimoto ${ }^{1}$, and Chiiho Fujiii
}

\begin{abstract}
Objective and Background: Although short-duration, high-dose glucocorticoid therapy is reportedly ineffective for early-phase acute respiratory distress syndrome (ARDS), steroid pulse therapy is often used in Japan for life-threatening cases because of its beneficial effects on oxygenation. Thus, we evaluated the effect of steroid pulse therapy on oxygenation for early-phase ARDS. Method: Cases of earlyphase ARDS treated with steroid pulse therapy in intensive care units of four critical care medical centers in Japan from 2000 to 2003 were investigated. Clinical course and serial changes in $\mathrm{PaO}_{2} / \mathrm{F}_{\mathrm{I}} \mathrm{O}_{2}$ ratio were evaluated. Results: Twenty-nine patients received methylprednisolone $1 \mathrm{~g} /$ day for 3 days; 20 patients subsequently received prolonged methylprednisolone treatment. Causes of ARDS were pneumonia $(n=23)$, extrapulmonary sepsis $(n=4)$ and other factors $(n=2)$. The overall mortality rate was $24.1 \% \cdot \mathrm{PaO}_{2} / \mathrm{FIO}_{2}$ ratios improved significantly after initiation of steroid pulse therapy, in comparison to pretreatment values (day 0: $119.8 \pm 30.6$, day 1: $172.1 \pm 63.7^{*}$, day $2: 196.4 \pm 90.0^{*}$, day 3: $218.4 \pm 92.0 *$, mean $\pm \mathrm{SD}, * \mathrm{p}<0.05$ vs. day 0). Significant improvement in oxygenation was observed in both survivors and non-survivors, but the $\mathrm{PaO}_{2} / \mathrm{F}_{\mathrm{I}} \mathrm{O}_{2}$ ratio in non-survivors subsequently deteriorated. In seven patients with life-threatening hypoxemia $\left(\mathrm{PaO}_{2} / \mathrm{FIO}_{2}\right.$ ratio $<100$ at day 0$)$, oxygenation improved significantly after pulse treatment; five of these patients survived. Conclusions: Three day steroid pulse therapy can improve oxygenation in patients with progressive ARDS even in the early phase. Steroid therapy for early-phase ARDS should be reconsidered.
\end{abstract}

(JJAAM $2007 ; 18: 1-9$ )

Keywords: ARDS, steroid pulse therapy, oxygenation Accepted for publication on May 1, 2006 (06-026)

\section{Introduction}

Acute respiratory distress syndrome (ARDS), characterized by diffuse inflammation of the alveolar-capillary

\footnotetext{
${ }^{1}$ Department of Traumatology and Acute Critical Medicine, Osaka University Graduate School of Medicine

${ }^{2}$ Saiseikai Senri Hospital Senri Critical Care Medical Center

${ }^{3}$ Nakakawachi Medical Center of Acute Medicine

${ }^{4}$ Senshu Critical Care Medical Center

${ }^{5}$ Sakai Municipal Hospital

${ }^{6}$ Asahikawasou Minamiehime Hospital

Corresponding author:

Yuka Sumi, MD

Critical Care and Trauma Center

Osaka Prefectural Hospital Organization, Osaka General Medical Center

3-1-56 Mandai-higashi, Sumiyoshi-ku, Osaka-shi, Osaka 558-8558

Japan
}

membrane in response to various pulmonary and extrapulmonary insults, is a major cause of morbidity in intensive care units. Although mortality from ARDS has decreased in the last decade ${ }^{1}$, it remains high (30-40\%), with most non-survivors dying within 2 weeks of disease development. The common pathologic feature of ARDS is an inflammatory process involving complex interaction between platelets, leukocytes, mononuclear cells, macrophages, and endothelial cells ${ }^{2}$. Dysregulation of cellular responses often occurs, and diffuse lung injury causes spillover of cytokines and other inflammatory and thrombotic mediators into the blood stream, which can lead to multiorgan system dysfunction. Pharmacologic treatment of ARDS patients focuses on attenuating these inflammatory responses ${ }^{3)}$.

Although most pharmacologic ARDS therapies have been shown to be ineffective, glucocorticoids, which inhibit the inflammatory process at virtually all levels ${ }^{4}$, have been used in the treatment of ARDS since the syndrome 
was first described over 35 years ago ${ }^{5)}$. Previous studies have concluded that glucocorticoids are not particularly effective against early ARDS but may have a role in the late phase ${ }^{6}$. High-dose glucocorticoid treatment is indicated only for the subgroups of acute lung injury /ARDS patients who have Pneumocystis carinii pneumonia ${ }^{7)}$ or are at risk of ARDS due to fat embolization ${ }^{8)}$. But, practically, we often experience deteriorated ARDS patients who could not survive without steroid administration in early phase.

In many facilities in Japan, 3-day steroid pulse therapy have been often used for life-threatening ARDS on the basis of observation of its beneficial effects on oxygenation in the declining clinical course. There have been a few reported cases showing the efficacy of steroid pulse therapy for ARDS patients ${ }^{9-15)}$, but the precise effect or mechanism of this treatment has not been thoroughly investigated.

We conducted retrospective investigation of ARDS patients, received steroid pulse therapy in four critical care medical centers in Osaka, Japan during the past 3 years. The objective of the present study was to evaluate the effect of steroid pulse therapy on oxygenation for early-phase progressive ARDS patients.

\section{Methods}

The subjects of this retrospective study were ARDS patients who underwent steroid pulse therapy during the period 2000 to 2003 in intensive care units of four critical care medical centers in Osaka, Japan: Department of Traumatology at Osaka University Medical School, Senri Critical Care Medical Center, Nakakawachi Medical Center of Acute Medicine, and Senshu Critical Care Medical Center. The collected data consisted of patient demographics, serial changes in clinical and laboratory factors, therapy, complications, and mortality.

ARDS was defined as acute-onset bilateral infiltrates depicted on the chest radiograph; hypoxia, defined as a ratio of $\mathrm{PaO}_{2}$ to the fraction of inspired oxygen $\left(\mathrm{FIO}_{2}\right)(\mathrm{PF}$ ratio) less than 200; and the absence of left atrial hypertension according to the revised definition proposed by American-European Consensus Conference on ARDS ${ }^{16}$.

There were 54 ARDS patients who were treated with steroid pulse therapy; 52 of these patients (96.3\%) were treated with methylpredonisolone in the early phase of ARDS (duration of ARDS $\leq 7$ days). Of these 52 patients, 23 with significant comorbid disease (severe chronic liver disease, severe chronic respiratory disease, burns requir-
Table 1. Patient characteristics $(n=29)$.

\begin{tabular}{ll}
\hline Age $(\mathrm{yr})$ & $57.3 \pm 21.0($ range, 14-80) \\
Sex $($ M/F $)$ & $20 / 9$ \\
Duration of ARDS (days)* & $2.5 \pm 2.1($ mean \pm SD) \\
Origin of ARDS & \\
\multicolumn{1}{c}{ Direct injury $(\mathrm{n}=25)$} & pneumonia $(\mathrm{n}=23)$ \\
& pulmonary contusion $(\mathrm{n}=1)$ \\
& chemical aspiration $(\mathrm{n}=1)$ \\
& extrapulmonary sepsis $(\mathrm{n}=4)$ \\
& pelvic abscess $(\mathrm{n}=1)$ \\
& peritonitis $(\mathrm{n}=1)$ \\
& pancreatitis $(\mathrm{n}=1)$ \\
& VAHS $(\mathrm{n}=1)$ \\
\hline
\end{tabular}

* At the time steroid pulse therapy was initiated.

$\dagger$ VAHS: virus- associated hemophagocytic syndrome

ing skin grafting), clinical evidence of active untreated infection, and extracorporeal support of gas exchange were excluded to permit evaluation of the precise effect of steroid pulse therapy on the clinical course. The exclusion criteria were selected from the criteria used in the Late Steroid Rescue Study by ARDS network (http:// www.ardsnet.org/). The remaining 29 patients (twenty men, nine women; mean age $57.3 \pm 21.0$ years, range 14 80 years) comprised the study subjects. Mechanical ventilation was based on lung protective strategy (Tidal Volume $<10 \mathrm{ml} / \mathrm{kg}$ of body weight, Peak airway pressure $<$ $35 \mathrm{cmH}_{2} \mathrm{O}$ ). The major clinical disorders associated with the development of ARDS were pneumonia $(n=23)$, extrapulmonary sepsis $(n=4)$, and others $(n=2)$ (Table 1). The pathogens to cause pneumonia were K.pneumoniae $(\mathrm{n}=2)$, P.aeruginosa $(\mathrm{n}=3)$, Chlamydia $(\mathrm{n}=1)$, E.coli $(\mathrm{n}$ $=1)$, Legionella $(\mathrm{n}=1)$, methicillin- resistant Staphylococcus aureus $(\mathrm{n}=1)$, while those in 14 cases were undetermined. APACHE II score on day 0 was $16.4 \pm 6.2$.

All 29 patients received MP pulse treatment $(1 \mathrm{~g} /$ day for 3 days) in the early phase of ARDS, and 20 patients subsequently received prolonged MP depending on their clinical response to MP (mean duration of $11.0 \pm 4.8$ days, mean $\pm \mathrm{SD}$ ). The mean interval between meeting the criteria for ARDS and the initiation of MP treatment was 2.5 \pm 2.1 days.

\section{§ Statistical analysis}

Data are expressed as mean \pm SD. Categorical variables were analyzed by chi-square test (Fisher's exact test). Continuous variables were analyzed by unpaired $t$ test. For each arm, mean values on days of treatment were contrasted with values on day 0 (day of initiation of steroid 
Table 2. Patient characteristics (Survivors vs. Non-survivors).

\begin{tabular}{lccc}
\hline Clinical Data & $\begin{array}{c}\text { Survivors } \\
(\mathrm{n}=22)\end{array}$ & $\begin{array}{c}\text { Non-survivors } \\
(\mathrm{n}=7)\end{array}$ & $\mathrm{p} \mathrm{value}^{\dagger}$ \\
\hline Mean age $(\mathrm{yr})$ & $54.1 \pm 23.0$ & $62.9 \pm 22.7$ & 0.38 \\
Sex $(\mathrm{M} / \mathrm{F})$ & $18 / 4$ & $2 / 5$ & 0.008 \\
Primary diagnosis & & & \\
$\quad$ Pneumonia & 18 & 5 & $\mathrm{NS}$ \\
Extrapulmonary sepsis & 2 & 2 & $\mathrm{NS}$ \\
Other & 2 & 0 & $\mathrm{NS}$ \\
$\mathrm{PaO}_{2} / \mathrm{F}_{\mathrm{IO}}$ at day $0 *$ & $125.3 \pm 31.9$ & $104.1 \pm 20.8$ & 0.61 \\
$\mathrm{PEEP}^{\ddagger}\left(\mathrm{cmH}_{2} \mathrm{O}\right)$ at day $0 *$ & $11.0 \pm 5.2$ & $11.0 \pm 3.5$ & 0.98 \\
\hline
\end{tabular}

Numbers of patients are shown unless otherwise indicated.

* day 0: the day of methylprednisolone was started.

Values are mean \pm SD.

${ }^{\dagger}$ With chi-square test; NS: not significant.

PEEP: positive end-expiratory pressure.

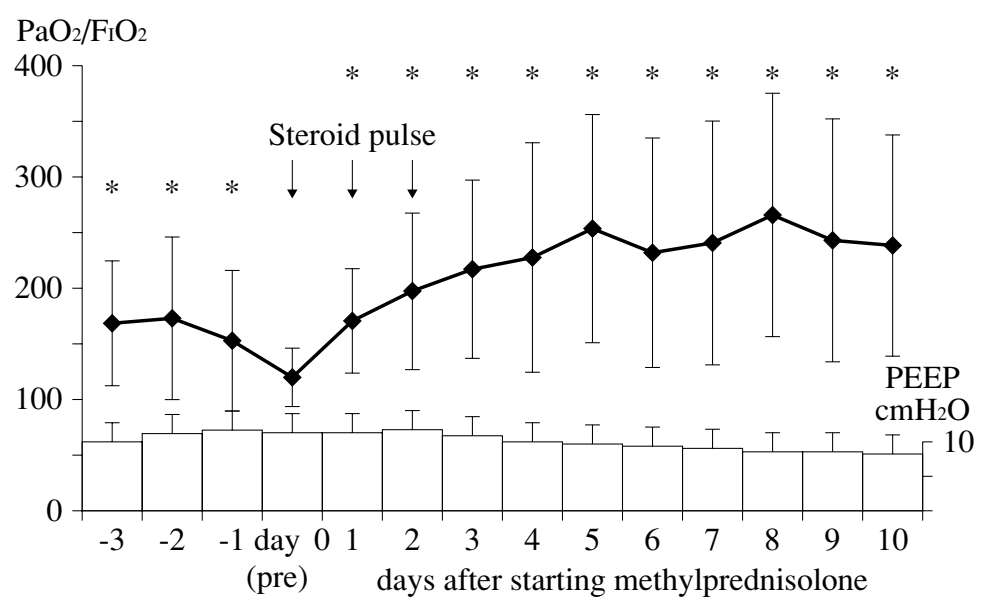

Fig. 1. Changes in $\mathrm{PaO}_{2} / \mathrm{F}_{1} \mathrm{O}_{2}(\mathrm{PF})$ ratio and PEEP in all patients $(\mathrm{n}=29)$. (Data are expressed as mean \pm SD.). At the initiation of steroid therapy (day 0 , before administration of methylprednisolone), the mean PF ratio was $119.8 \pm$ 30.6 , significantly decreased in comparison to that on previous days $(\mathrm{p}<0.05)$. The PF ratio improved significantly on the first, second, and third days after the start of steroid pulse therapy, in comparison to the pretreatment value, though PEEP was almost unchanged. ${ }^{*} \mathrm{p}<0.05$ vs. day 0 (pre).

therapy before administration of MP). We used ANOVA of repeated test to evaluate serial change of $\mathrm{PF}$ ratio in survivors and non-survivors. In addition, partial correlation coefficients were estimated to quantify the relation between the $\mathrm{PF}$ ratio, clinical variables, and clinical course. A p value of $<0.05$ was considered significant.

\section{Results}

Of the 29 patients with progressive early-phase ARDS recieved steroid pulse therapy, 22 survived $(75.9 \%)$ and seven died (24.1\%). Non-survivors were significantly more likely to be female (M: $\mathrm{F}=2: 5$ ) in comparison to survivors $(\mathrm{p}<0.05)$ (Table 2). The causes of death were respiratory failure $(57.1 \%, \mathrm{n}=4)$ and septic shock $(42.9 \%, \mathrm{n}=$ 3 ). The non-survivors died on day $25.3 \pm 14.2$ (range, day 6-45) after starting MP pulse treatment. Among the seven non-survivors, the primary diagnosis was pneumonia $(\mathrm{n}=$ $5)$, peritonitis $(\mathrm{n}=1)$, and virus-associated hemophagocytic syndrome $(\mathrm{n}=1)$.

Changes in the mean PF ratio in all patients are shown in Fig. 1. At the initiation of steroid therapy (day 0), the 


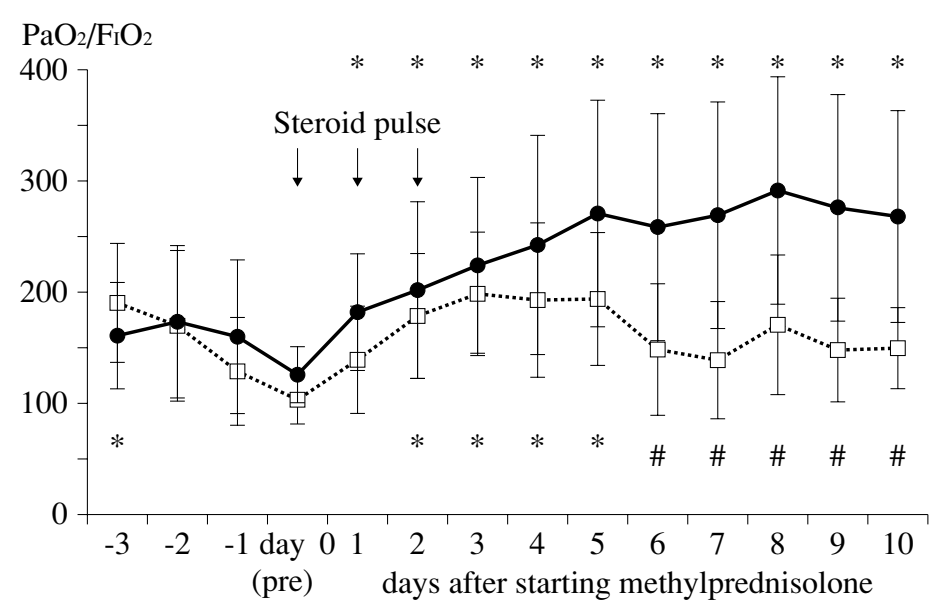

Fig. 2. Changes in $\mathrm{PaO}_{2} / \mathrm{FIO}_{2}$ (PF) ratio (survivors vs. non-survivors). (Data are expressed as mean \pm SD. Closed circle express survivors, open square with a dotted line express non-survivors.). A significant improvement in oxygenation after the start of steroid pulse therapy was observed in both survivors $(n=22)$ and non-survivors $(n=7)(p<0.05)$, but the PF ratio in non-survivors subsequently decreased. From day 6 after the start of treatment, the PF ratio was significantly lower in the non-survivors than in the survivors $(\mathrm{p}<0.05){ }^{*} \mathrm{p}<0.05$ vs. day $0, \# \mathrm{p}<0.05$ vs. survivors.

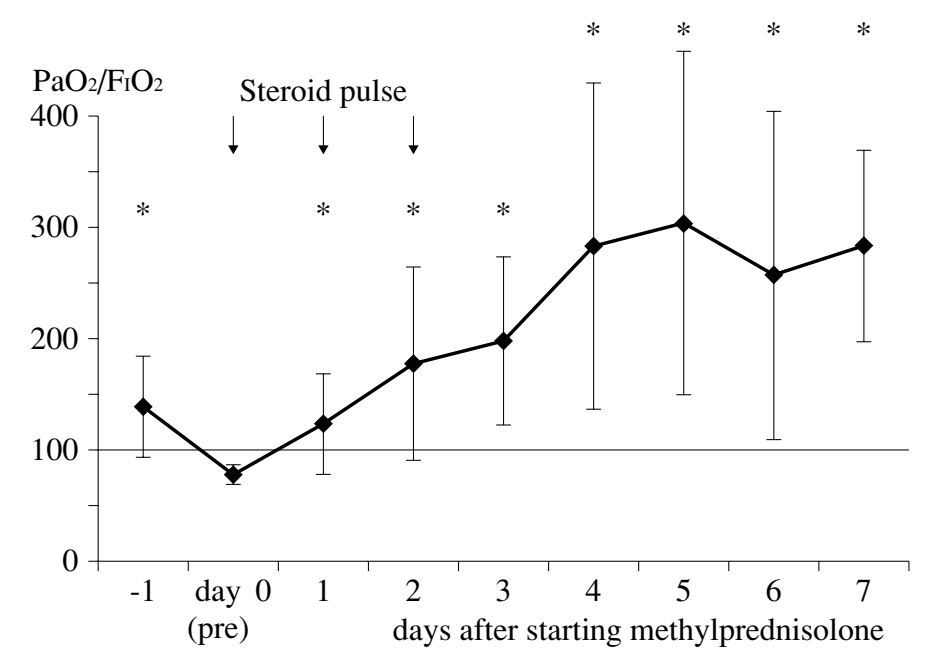

Fig. 3. Changes in $\mathrm{PaO}_{2} / \mathrm{F}_{1} \mathrm{O}_{2}$ (PF) ratio in seven life-threatening acute respiratory distress syndrome patients $(\mathrm{PF}$ ratio $<100$ at day 0$)$. (Data are expressed as mean \pm SD.) The mean PFratio improved significantly after the start of steroid pulse therapy. $* \mathrm{p}<0.05$ vs. day 0 .

mean $\mathrm{PF}$ ratio was $119.8 \pm 30.6$ and positive end-expiratory pressure was $11.0 \pm 4.8 \mathrm{cmH}_{2} \mathrm{O}$. The $\mathrm{PF}$ ratio on day 0 was significantly decreased in comparison to that on previous days $(\mathrm{p}<0.05)$. The PF ratio improved significantly on the first day, the second day, and the third day after initiation of steroid pulse therapy in comparison to the pretreatment (day 0) value (day 0: $119.8 \pm 30.6$, day 1 : $172.1 \pm 63.7^{*}$, day $2: 196.4 \pm 90.0^{*}$, day $3: 218.4 \pm 92.0^{*}$, *p $<0.05$ vs. day 0 ), though PEEP was almost unchanged. The serial changes in the mean PF ratio in survivors and non-survivors are shown in Fig. 2. Significant improvement in oxygenation after the start of steroid pulse therapy was observed in both survivors and non-survivors $(\mathrm{p}<$ $0.05)$, but the PF ratio in the non-survivors subsequently deteriorated. From day 6 after the initiation of treatment, the PF ratio in non-survivors was significantly lower than 
Table 3. Complications.

\begin{tabular}{lcc}
\hline & $\begin{array}{c}\text { Survivors } \\
(\mathrm{n}=22)\end{array}$ & $\begin{array}{c}\text { Non-survivors } \\
(\mathrm{n}=7)\end{array}$ \\
\hline Bacteremia & $6(27 \%)$ & $5(71 \%)^{*}$ \\
Hyperglycemia & $12(55 \%)$ & $4(57 \%)$ \\
Gastrointestinal bleeding & $1(5 \%)$ & $1(14 \%)$ \\
\hline
\end{tabular}

Number (and percentage) of patients are shown.

With chi-square test, $* \mathrm{p}<0.05$ vs. survivors

that in survivors $(\mathrm{p}<0.05)$.

Even in the seven patients with life-threatening hypoxemia $(\mathrm{PF}$ ratio $<100$ at day 0$)$, the mean $\mathrm{PF}$ ratio was significantly improved after initiation of steroid pulse therapy (Fig. 3). Five of these patients survived (mortality rate of $28.6 \%$ ), and two patients died due to septic shock, one on day 6 and one on day 29. There are no statistically significant difference about SOFA score on day 0 (7.4 \pm 3.8 v.s. $8.1 \pm 3.7)$, day3 $(5.5 \pm 3.6$ v.s. $7.4 \pm 3.7)$, day 7 $(3.5 \pm 2.8$ v.s. $5.5 \pm 3.8)$ and day $10(3.1 \pm 2.7$ v.s. $5.2 \pm$ 3.6) between survivors and non-survivors (mean $\pm \mathrm{SD}$ ). But, serial changes in SOFA score was siginificantly different between survivors and non-survivors $(p=0.02)$.

With respect to complications, the hyperglycemia and gastrointestinal bleeding occurred with similar frequency in survivors and non-survivors, but the frequency of bacteremia was significantly higher in the non-survivors $(\mathrm{p}<$ 0.05 , Table 3). Bacteremia in the non-survivors was caused by Enterococcus $(\mathrm{n}=3)$, methicillin-resistant Staphylococcus aureus $(\mathrm{n}=1)$, and Candida $(\mathrm{n}=1)$.

\section{Discussion}

In the present study, we found that steroid pulse therapy for 3 days can improve oxygenation in patients with earlyphase progressive ARDS. Our data shows that although steroid pulse therapy was initiated at the point when the clinical course was declining, pulmonary oxygenation improved rapidly after the start of treatment, with an overall survival rate of $75.9 \%$. These remarkable results of steroid pulse therapy were observed both in survivors and non-survivors. Even in the life-threatening ARDS cases ( $\mathrm{PF}$ ratio $<100$ at day 0 ), in which we had no other therapeutic alternatives, oxygenation recovered dramatically after the initiation of steroid pulse therapy, and all patients were salvaged during the 3 -day treatment, with a $71.4 \%$ intensive care unit survival rate. These results suggest that steroid pulse therapy can exert a beneficial effect on poor oxygenation and reverse the life-threatening course of pro- gressive ARDS in the early phase.

Glucocorticoids inhibit the inflammatory pathways at all levels and exert most of their influence via specific, ubiquitously distributed intracellular glucocorticoid receptors. The dosage for steroid pulse therapy (MP $1 \mathrm{~g} /$ day for 3 days) was first chosen after experience in treating graft rejection in renal transplant recipients in $1976^{17)}$. This MP pulse treatment has been used for patients with severe manifestations of autoimmune diseases such as systemic lupus erythematosus ${ }^{18)}$, dermatomyositis ${ }^{19)}$, and Still's disease $^{9)}$, and rapid beneficial effects on the clinical course were reported repeatedly. In these reports, steroid pulse therapy was described as having a strong anti-inflammatory effect on exaggerated inflammatory response in organ and/or life-threatening conditions.

The duration of efficacy of administered MP is 24 to 72 hours after the pulse dose and does not change significantly even with higher doses. After 24 hours, approximately $99 \%$ of the MP pulse dose is eliminated. These characteristics of MP pulse therapy result in decreased steroid-related side effects, such as suppression of the hypothalamic-pituitary- adrenal axis, in comparison to oral prednisolone (20 mg daily) treatment for as few as 5 days ${ }^{20}$. In previous studies in humans and rabbits, greater concentrations of MP than of prednisolone appeared in the lung, in part because of the greater tendency of MP to be retained in the epithelial lining fluid ${ }^{21}$. Recent in-vitro studies showed that MP pulse therapy produces strong antiinflammatory action through immediate effects on lymphocyte activation by interacting directly with the cell membrane and decreasing intracellular $\mathrm{Ca}^{2+}$ concentrations. These results indicate additional therapeutic benefits of MP pulse therapy in comparison to low-dose prednisolone therapy because of nongenomic effects mediated by membrane-bound receptors and initiated by physiochemical interactions with cellular membranes.

Our study is the first in vivo study to evaluate the efficacy of steroid pulse therapy on oxygenation for early-phase ARDS of various origins. A few reports in the English literature describe the efficacy of steroid pulse therapy for ARDS patients with specific disease. Ho et al ${ }^{11)}$. recently reported that severe acute respiratory syndrome patients initially treated with steroid pulse therapy had a lesser oxygen requirement and better radiographic outcome than patients treated with non-pulse steroid therapy. They suggest that initial use of pulse methylprednisolone therapy is more efficacious and equally safe steroid regimen when compared with regimens with lower dosage. Trivedi et al ${ }^{12}$. showed that early steroid pulse therapy after the onset of dyspnea 
can reverse the lethal pulmonary involvement of leptospirosis. A beneficial effect of steroid pulse therapy was reported in ARDS patients with leukopenic pneumococcal pneumonia ${ }^{13)}$, petroleum naphtha ingestion ${ }^{14)}$, chronic granulomatous disease following pulmonary invasive aspergillosis ${ }^{10)}$, and rapid- progressive bronchiolitis obliterans organizing pneumonia ${ }^{15)}$. The regimen of methylprednisolone (500mg-1g/day for 3-5 days) in these studies is similar to our regimen. These reports are consistent with our findings that deteriorated oxygenation recovered significantly after the initiation of steroid pulse therapy even in cases in which the disease had progressed to a life-threatening stage.

A prospective randomized trial ${ }^{22)}$ was reported in which high-dose MP did not affect the outcome of patients with established ARDS due to sepsis, aspiration, or mixed causes. The investigators started MP $(30 \mathrm{mg} / \mathrm{kg}$ every 6 hours for 24 hours) in patients within 48 hours after diagnosing ARDS. Principally because of these results, highdose MP treatment for early-phase ARDS has been considered ineffective. However, there were several factors in their study that inhibit precise evaluation of the effect of steroid treatment in early-phase ARDS. First, almost half of their patients (44\%) suffered severe active infection including bacteremia upon entering the study, and mortality rates in both the treatment group and placebo group were significantly high (about $60 \%$ ). Second, the corticosteroid regimen $(30 \mathrm{mg} / \mathrm{kg}$ every 6 hours to four doses) lasted only 1 day, and there was no additional treatment until resolution. Thus, there were strong non-pulmonary determinants of outcome in their study, and the treatment period might have been too short to produce a constant effect.

In another prospective trial, Luce et al ${ }^{23)}$. found that high-dose MP treatment given in the similar regimen reported by Bernard et $\mathrm{al}^{22}$. did not affect the incidence of ARDS or hospital mortality in sepsis patients at high risk for developing ARDS. In our study, patients with bacteremia were excluded, and steroid therapy lasted at least 3 days. Moreover, ARDS was caused by direct pulmonary injury in more than $80 \%$ of our patients. Considering these differences in the patient group and treatment regimen, our findings of beneficial effects of steroid pulse therapy in early-phase ARDS do not contradict the previous reports that ruled out high-dose MP for patients at risk or with early ARDS. Mervyn et al ${ }^{24)}$. found that hydrocortisone $(800 \mathrm{mg} /$ day for 48 hours) was useful in the treatment of previously healthy patients with early-phase lifethreatening varicella pneumonia. Confalonieri et al. re- cently reported that hydrocortisone treatment (200mg bolus plus $240 \mathrm{mg} /$ day for 7 days) improved the clinical course in severe acquired pneumonia ${ }^{25)}$. Thus, further study is needed to determine the appropriate indications and treatment regimen for steroid therapy in patients with earlyphase ARDS.

In our study, oxygenation in the survivors continued to improve after steroid pulse therapy, whereas oxygenation in the non-survivors subsequently deteriorated. Prolonged steroid therapy for a mean duration of 9.8 days after the pulse therapy was used in $68.2 \%$ of the survivors. The efficacy of prolonged steroid treatment in late-phase ARDS patients has been controversial. Meduri et al ${ }^{6,26)}$. reported that prolonged administration of MP (initial dose of $2 \mathrm{mg} /$ $\mathrm{kg} /$ day, tapered over 32 days) in patients with unresolving ARDS was associated with improvement in lung injury and reduced mortality; this was a controlled study with a small number of patients. Biffl et al ${ }^{27)}$. also found that MP therapy (1-2 mg/kg every 6 hours for a mean duration of 21.3 days) significantly improved oxygenation and lung injury score in six patients with refractory late-phase ARDS, and saved five patients in life-threatening condition. On the other hand, Late Steroid Rescue Study of ARDS network found that prolonged methylprednisolone has not improved the outcome of persistent ARDS patients despite the improvement in cardiopulmonary physiology ${ }^{28)}$.

In addition to its antiinflammatory properties, MP is known to inhibit proliferation of fibroblasts and synthesis of collagen by fibroblasts in tissue cultures ${ }^{29}$. The use of steroid in the late phase of ARDS is based on the assumption that the fibroproliferative phase begins 7-10 days after insult. However, some investigators report that the proliferative phase begins much sooner. Rocco et al. found that corticosteroid treatment in the early phase of acute lung injury improved in vivo and in vitro respiratory mechanics, acting on the remodeling process, mechanism by which oxygenation was significantly improved in both the early phase and late and significantly reducing collagen fiber deposition ${ }^{30}$. This may partly explain the phase with the use of MP therapy in our study.

In an analysis of notable complications after the start of steroid pulse therapy, we found that hyperglycemia and gastrointestinal bleeding occurred with similar frequency between survivors and non-survivors, whereas bacteremia was significantly more frequent among non-survivors (71\%). Thus, bacteremia can be considered an important determinant of clinical outcome in ARDS patients treated with steroid pulse therapy. Because bacteremia occurs 
around 15 days after the start of steroid treatment, appropriate and repeated use of antimicrobic drugs should be considered during steroid treatment on the basis of information obtained from bacterial cultures repeated every 3 to 4 days. Our study was an uncontrolled retrospective study; a prospective randomized study is needed to clarify both the efficacy and risk of steroid pulse therapy for earlyphase ARDS.

In the present study, the non-survivors in comparison to survivors were significantly more likely to be female. Although ARDS comprises clinically heterogeneous syndromes of various causes and clinical courses, sex-specific and genetic susceptibilities have been investigated. Kollef et al ${ }^{31)}$. reported a greater risk of hospital mortality for women requiring mechanical ventilation than for men with equivalent requirements, which is consistent with our findings in ARDS patients. Gong et a ${ }^{32}$. showed that the variant polymorphism of the surfactant protein-B gene is associated with ARDS and with direct pulmonary injury in women, but not in men. These reports may support the hypothesis that individual difference in susceptibility to developing ARDS depends on sex and genotype. The utility of steroid treatment in patients with different genetic susceptibilities is yet to be elucidated.

\section{Conclusions}

Steroid pulse therapy for 3 days can improve oxygenation even in the early phase of progressive ARDS. Steroid therapy for early-phase ARDS should be reconsidered, and further prospective randomized studies need to be conducted to clarify the efficacy of steroid pulse therapy in patients with ARDS.

\section{References}

1) Milberg JA, Davis DR, Steinberg KP, et al: Improved survival of patients with acute respiratory distress syndrome (ARDS): 1983-1993. JAMA 1995; 273: 306-9.

2) Vincent JL:New management strategies in ARDS: immunomodulation. Crit Care Clin 2002; 18: 69-78.

3) Matthay MA, Zimmerman GA, Esmon C, et al: Future research directions in acute lung injury. Summary of a National Heart, Lung and Blood Institute working group. Am J Respir Crit Care Med 2003; 167: 1027-35.

4) Meduri GU: The role of the host defence response in the progression and outcome of ARDS: pathophysiological correlations and response to glucocorticoid treatment. Eur Respir J 1996; 9: 2650-70.

5) Ashbaugh DG, Bigelow DB, Petty TL, et al: Acute respira- tory distress in adults. Lancet $1967 ; 7511: 319-23$.

6) Meduri GU, Tolley EA, Chrousos GP, et al: Prolonged methylprednisolone treatment suppresses systemic inflammation in patients with unresolving acute respiratory distress syndrome: evidence for inadequate endogenous glucocorticoid secretion and inflammation-induced immune cell resistance to glucocorticoids. Am J Respir Crit Care Med 2002; 165: 983-91.

7) Montaner JS, Lawson LM, Levitt N, et al: Corticosteroids prevent early deterioration in patients with moderately severe Pneumocystis carinii pneumonia and the acquired immunodeficiency syndrome (AIDS). Ann Intern Med 1990; 113: 14-20.

8) Schonfeld SA, Ploysongsang Y, DiLisio R, et al: Fat embolism prophylaxis with corticosteroids. A prospective study in high-risk patients. Ann Intern Med 1983; 9: 438-43.

9) Iglesias J, Sathiraju S, Marik PE: Severe systemic inflammatory response syndrome with shock and ARDS resulting from Still's disease: clinical response with high-dose pulse methylprednisolone therapy. Chest 1999; 115: 1738-40.

10) Okano M, Yamada M, Ohtsu M, et al: Successful treatment with methylprednisolone pulse therapy for a life-threatening pulmonary insufficiency in a patient with chronic granulomatous disease following pulmonary invasive aspergillosis and Burkholderia cepacia infection. Respiration 1999; 66: 551-4.

11) Ho JC, Ooi GC, Mok TY, et al: High-dose pulse versus non pulse corticosteroid regimens in severe acute respiratory syndrome. Am J Respir Crit Care Med 2003; 168: 1449-56.

12) Trivedi SV, Chavda RK, Wadia PZ, et al: The role of glucocorticoid pulse therapy in pulmonary involvement in leptospirosis. J Assoc Physicians India 2001; 49: 901-3.

13) Yokoyama $T$, Sakamoto $T$, Shida $N$, et al: Bacteremic and leukopenic pneumococcal pneumonia: successful treatment with antibiotics, pulse steroid, and continuous hemodiafiltration. J Infect Chemother 2002; 8: 247-51.

14) Kamijo Y, Soma K, Asari Y, et al: Pulse steroid therapy in adult respiratory distress syndrome following petroleum naphtha ingestion. J Toxicol Clin Toxicol 2000; 38: 59-62.

15) Husain SJ, Irfan M, Zubairi AS, et al: Rapidly-progressive bronchiolitis obliterans organising pneumonia. Singapore Med J 2004; 45: 283-5.

16) Bernard GR, Artigas A, Brigham Kl, et al: The AmericanEuropean Consensus Conference on ARDS. Definitions, mechanisms, relevant outcomes, and clinical trial coordination. Am J Respir Crit Care Med 1994; 149: 818-24.

17) Mussche MM, Ringoir SM, Lameire NN: High intravenous doses of methylprednisolone for acute cadaveric renal allograft rejection. Nephron 1976; 16: 287-91.

18) Badsha H, Edwards CJ: Intravenous pulses of methylprednisolone for systemic lupus erythematosus. Semin Arthritis Rheum 2003; 32: 370-7. 


\section{Yuka Sumi, et al}

19) Yanagisawa $T$, Sueishi M, Nawata $Y$, et al: Methylprednisolone pulse therapy in dermatomyositis. Dermatologica 1983; 167: 47- 51.

20) Garber EK, Fan PT, Bluestone R: Realistic guidelines of corticosteroid therapy in rheumatic disease. Semin Arthritis Rheum 1981; 11: 231-56.

21) Greos LS, Vichyanond P, Bloedow DC, et al: Methylprednisolone achieves greater concentrations in the lung than prednisolone. A pharmacokinetic analysis. Am Rev Respir Dis 1991; 144: 586-92.

22) Bernard GR, Luce JM, Sprung CL, et al: High-dose corticosteroids in patients with adult respiratory distress syndrome. N Engl J Med 1987; 317: 1565-70.

23) Luce JM, Montgomery AB, Marks JD, et al: Ineffectiveness of high-dose methylprednisolone in preventing parenchymal lung injury and improving mortality in patients with septic shock. Am Rev Respir Dis 1988; 138: 62-8.

24) Mer M, Richards GA:Corticosteroids in life-threatening varicella pneumonia. Chest 1998; 114: 426-31.

25) Confalonieri M, Urbino R, Potena A, et al: Hydrocortisone infusion for severe community-acquired pneoumonia. Am J Respir Crit Care Med 2005; 171: 242-8.
26) Meduri GU, Headly AS, Golden E, et al: Effect of prolonged methylprednisolone therapy in unresolving acute respiratory distress syndrome: a randomized controlled trial. JAMA 1998; 280: 159-65.

27) Biffl WL, Moore FA, Moore EE, et al: Are corticosteroids salvage therapy for refractory acute respiratory distress syndrome? Am J Surg 1995; 170: 591-6.

28) Steinberg KP, Hudson LD, Goodman RB, et al: Efficacy and safety of corticosteroids for persistent acute respiratory distress syndrome. N Engl J Med 2006; 354: 1671-84.

29) Thompson BT: Glucocorticoids and acute lung injury. Crit Care Med 2003; 31: S253-7.

30) Rocco PR, Negri EM, Kurtz PM, et al: Lung tissue mechanics and extracellular matrix remodeling in acute lung injury. Am J Respir Crit Care Med 2001; 164: 1067-71.

31) Kollef MH, O'Brien JD, et al: The impact of gender on outcome from mechanical ventilation. Chest 1997; 111:43441.

32) Gong MN, Wei Z, Xu LL, et al: Polymorphism in the surfactant protein-B gene, gender, and the risk of direct pulmonary injury and ARDS. Chest 2004; 125: 203-11. 
原著論文

\section{早期 ARDS 患者におけるステロイドパルス療法の酸素化改善効果}

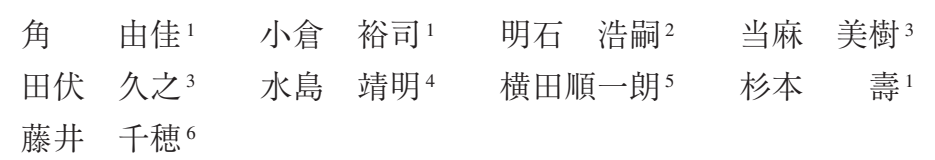

要旨 背景：欧米では早期 acute respiratory distress syndrome（以下ARDS と略す）に対する高容量ステロイドの 使用は否定されているが，本邦では臨床経験をもとに重症ARDSに対してステロイドパルス療法が行われてきた。 しかしながら, その有効性は十分評価されていない。本研究の目的は, 早期ARDS症例に対するステロイドパル ス療法の効果を多施設で検討することである。対象と方法：対象は，2000 年から 2003 年までの 3 年間に 4 つの 救命センターでARDSの診断基準を満たし, ARDS発症1週間以内にステロイドパルス療法を施行した29症例 (肺 炎23例,敗血症 4 例，その他 2 例)。全例の臨床経過挹よび酸素化能の推移を retrospective に評価した。結果：29 例全例メチルプレドニゾロン $1 \mathrm{~g} \times 3$ 日間のパルス療法を行い,うち 20 例はパルス療法後維持療法へと移行した。 ICU 死亡率は $24.1 \%$ であた。悪化中の $\mathrm{PF}$ 比 $\left(\mathrm{PaO}_{2} / \mathrm{F}_{1} \mathrm{O}_{2}\right)$ は，ステロイドパルス開始を契機に翌日より有意に改 善した (day 0: $119.8 \pm 30.6$, day 1: $172.1 \pm 63.7^{*}$, day 2: $196.4 \pm 90.0^{*}$, day 3: $218.4 \pm 92.0^{*}$, mean \pm SD, $* \mathrm{p}<0.05$ vs. day 0)。また, PF比100以下の致死的重症例もパルス療法によって有意な酸素化の改善がみられ，7例中 5 例の生存 を得た。総括：ステロイドパルス療法は，早期 ARDS患者の酸素化能を有意に改善する。早期ARDSにおけるス テロイド療法の適応を再検討すべきと考える。

(日救急医会誌 $2007 ; 18 ： 1-9$ )

キーワード：急性呼吸促迫症候群, ステロイドパルス療法, 酸素化

${ }^{1}$ 大阪大学大学院医学系研究科救急医学 2 済生会千里病院千里救命救急センター

${ }^{3}$ 大阪府立中河内救命救急センター 4 大阪府立泉州救命救急センター 5 堺市民病院 6 旭川荘南愛媛病院

著者連絡先：干 558-8558 大阪市住吉区万代東 3-1-56 大阪府立急性期・総合医療センター救急診療科

原稿受理日：2006 年 5 月 1 日 $(06-026)$ 